Tạp chí Khoa học và Công nghệ Biển T12 (2012). Số 4. Tr 52 - 61

\title{
PHÂN BỐ VÀ QUÁ TRÌNH VậN CHUYỂN CỦA TRỨNG CÁ VÀ CÁ BộT CỦA LOÀI CÁ CƠM SỌC XANH (Encrasicholina punctifer) Ở VÙNG NƯỚC TRỒI NAM TRUNG Bộ, VIỆT NAM
}

\author{
VÕ VĂN QUANG, TRẦ VĂN CHUNG
}

Viện Hải dương học Nha Trang

\begin{abstract}
Tóm tắt: Phân bố trứng cá và cá bột của loài cá cơm sọc xanh cho thấy sụ khác nhau giữa các tháng 7/2003, 4/2004, 7/2004 và 3/2005 ở vùng nước trồi phía Nam Việt Nam. Quá trình nuớc trồi đã tác động đến sinh sản của cá cơm sọc xanh, biểu hiện là mật độ trúng cao trong thời kỳ nước trồi hoạt động (tháng 6 - 8). Trúng cá của cá cơm sọc xanh phong phú trong tất cả các tháng thu mẫu nhung cao nhất vào tháng 7 năm 2003 và 2004. Mật độ cao của trứng cá nằm ở các trạm ven bờ (trạm 41, 42, 51, 52, 62, và 63). Quá trình nuơóc trồi đã kích thích đến loài cá cơm sọc xanh đẻ, điển hình mật độ trúng vào tháng 7 8 cao hơn tháng 3 - 4. Sư phân bố của cá bột không đồng nhất với vùng phân bố trúng cá, chứng tỏ có sự tác động của dòng chảy qua quá trình khuếch tán, vận chuyển và đưa cá bột đến khu vực ven bò̀ (các đảo và vịnh) nơ ương duỡng thuận lọi cho cá con trong quá trình bổ sung cho quần thể cá cơm sọc xanh.
\end{abstract}

\section{I. ĐẶT VẤN ĐỀ}

Nhiều đàn cá biển được cho là có quan hệ với suốt giai đoạn ấu thể phù du của chúng, đó là những cá thể cá bột và cá con phân tán từ bãi đẻ đến các bãi ương dưỡng [3]. Dấu hiệu của quá trình này được Hjor [1] ghi nhận bằng những thay đổi độ phong phú các đàn cá liên quan rất lớn từ tỉ lệ sống của nhóm cá mới được sinh ra trong năm mà trước khi chúng bổ sung cho quần đàn và bắt đầu được khai thác. Ông cũng đề xuất rằng (1) Sự vận chuyển đến bãi vơng dương tù bãi đẻ và (2) phần lớn cá bột bị chết do thiếu thức ăn khi chúng bắt đầu bắt mồi là những nguyên nhân tiềm tàng cho sự khác nhau mức độ phong phú các đàn cá trong các năm. Cơ chế sự vận chuyến, sự lưu giữ nguồn giống và mùa vụ sinh sản đã được ứng dụng và trở nên quan trọng đối với nghiên cứu cá biển, nó được đề cập trong nhiều tài liệu. Cơ sở lý thuyết của quá trình vận chuyển ấu thể cá là sự thay đổi phân bố địa lý của cá bột liên quan tới các bãi đẻ và có hay không sự tác động các yếu tố môi trường lên số lượng sống sót đến khi thành thục [15].

Hệ thống nước trồi đóng góp chính trong sản lượng nghề cá của thế giới, chiếm $25,1 \%$ tổng sản lượng cá khai thác ở biển trong giai đoạn 1985 - 1991 [14]. Quá trình nước trồi kích thích các đàn cá cơm sinh sản thông qua các đặc trưng hải dương, sinh học và môi trường, sự khác nhau về đặc trưng môi trường và năng suất sinh học giữa các khối nước ở các độ sâu khác nhau; nhất là năng suất sinh học sơ cấp và các yếu tố môi trường sống thuận lợi ở lớp nước bề mặt. Tuy nhiên mối quan hệ này không phải là một đường thẳng, cường độ nước trồi ở mức trung bình là thích hợp cho sự sinh sản cá bố mẹ và ương dưỡng cá bột [3]. Các quá trình môi trường và sinh học vùng nước trồi có vai trò quan trọng đến sự sống sót và bổ sung ở giai đoạn đầu của cá vào quần thể. 
Vùng nước trồi nằm ngoài khơi khu vực Nam Trung bộ đã được ghi nhận vào mùa gió Tây Nam và đã được nhiều tác giả nghiên cứu về phạm vi, đặc điểm của nó, với dòng chảy tầng mặt về hướng Đông - Đông Bắc bao trùm hết thềm lục địa, tác động trên toàn bộ mặt biển. Tốc độ trung bình của dòng chảy tăng dần theo hướng từ bờ ra khơi cho đến một dải giá trị cực đại là luồng chảy mạnh $[6,7,20]$.

Cá cơm sọc xanh là loài cá nhỏ sống ven bờ có sản lượng khai thác khá lớn, là một trong những loài cá biển có giá trị kinh tế, chúng được chế biến thành nước mắm, phơi khô hoặc ăn tươi. Loài cá cơm sọc xanh có sản lượng khá lớn ở các địa phương gần vùng nước trồi Nha Trang, Phan Rang, Phan Rí, Phan Thiết [12].

Kết quả bài báo phân tích sự phân bố trứng cá và cá bột về mặt không gian, thời gian và mô phỏng về sự vận chuyển cá bột của chúng dưới tác động quá trình thủy động lực làm phong phú thêm về ý nghĩa nước trồi đối với nguồn lợi thủy sản nói chung và cá nói riêng, cũng như quá trình bồ sung quần đàn cá của loài cá cơm sọc xanh trong hệ sinh thái này ở vùng biển Nam Trung bộ.

\section{PHƯƠNG PHÁP NGHIÊN CÚU}
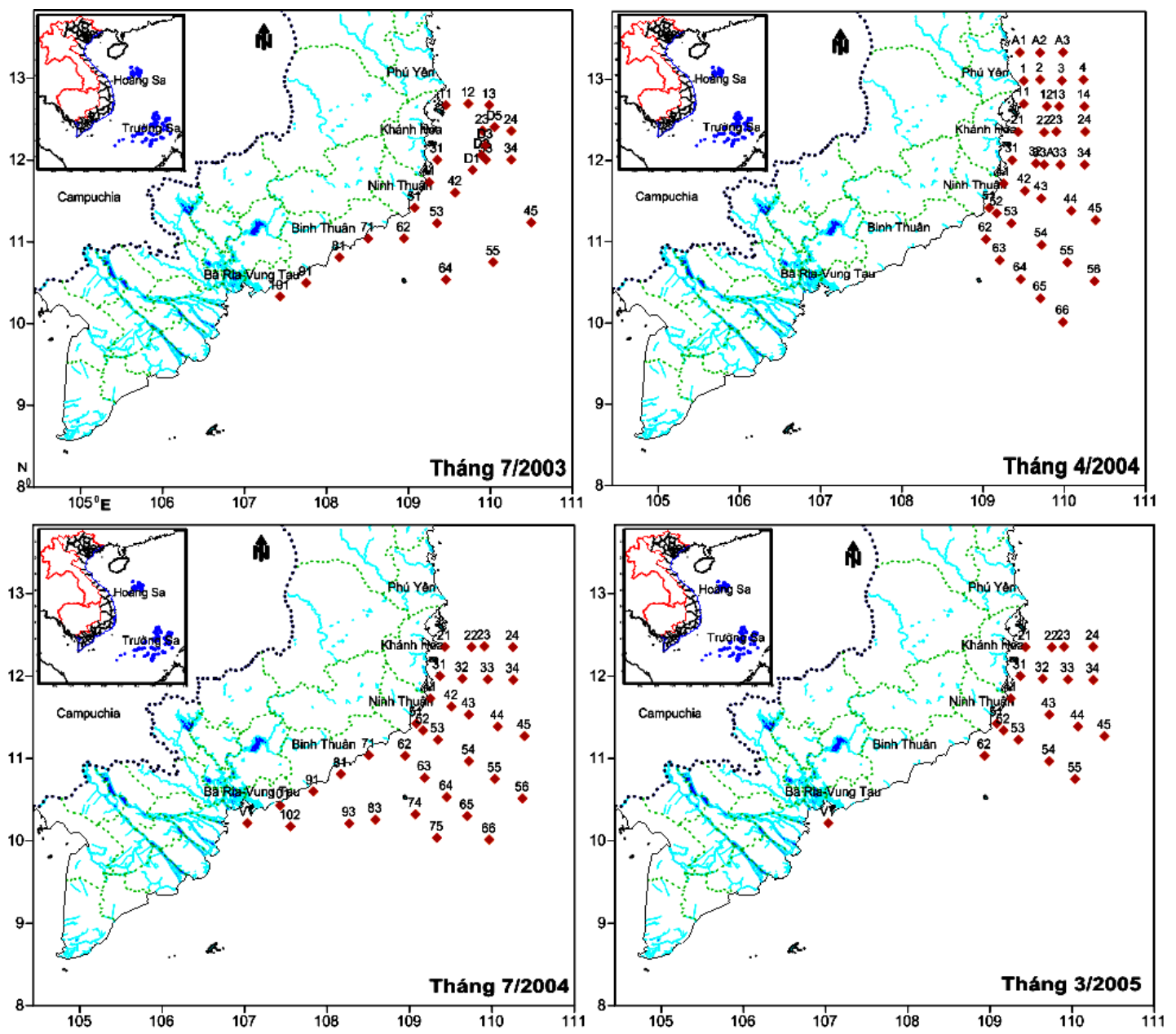

Hình 1. Sơ đồ các vị trí trạm thu mẫu các chuyến khảo sát theo tháng 
Tiến hành thu mẫu trên vùng biển Nam Trung bộ, từ Phú Yên đến Bình Thuận, trong 4 chuyến thuộc chương trình hợp tác Việt Nam - Đức; vào tháng 7/2003 , 4/2004, 7/2004 và 3/2005. Khu vực lựa chọn phân tích nằm trong khung màu vàng (hình 1)

Thu thập mẫu bằng lưới tầng mặt: có dạng hình chóp tứ giác, dùng vớt mẫu ở tầng mặt. Miệng lưới hình chữ nhật: có chiều dài $90 \mathrm{~cm}$, rộng $56 \mathrm{~cm}$, diện tích miệng lưới $0,5 \mathrm{~m}^{2}$. Chiều dài toàn bộ là $269 \mathrm{~cm}$. Dùng vải lưới số $22\left(1 \mathrm{~cm}\right.$ chiều dài có $21-22$ lỗ, $1 \mathrm{~cm}^{2}$ có 460 lỗ mắt lưới), kích thước mỗi mắt lưới là $330 \mu \mathrm{m}$. Lưới được kéo trên tầng mặt với vận tốc 2 - $4 \mathrm{~km} /$ giờ. Mỗi mẻ lưới thu mẫu đều có gắn lưu tốc kế trên miệng lưới để tính thể tích nước qua lưới.

Phân loại trứng cá và cá bột cá cơm sọc xanh dựa trên tài liệu [4, 9, 10, 13, 21].

Mô phỏng vận chuyển của trứng cá loài cá cơm sọc xanh dựa trên mô hình dòng chảy tầng mặt theo mô hình 3 chiều bằng phương pháp phần tử hữu hạn. Một mạng lưới tam giác được thiết lập với mức độ phù hợp với đặc điểm địa hình khu vực (hình 2). Dòng chảy tầng mặt tổng hợp vào thời kỳ gió mùa Tây Nam (được tính trung bình theo tháng từ năm 1996 - 2008) (hình 3), các phương pháp tính [2]. Mô hình giả định rằng trứng được cá mẹ đẻ tại bãi đẻ, dưới tác động dòng chảy, sẽ được vận chuyển và khuếch tán theo dạng hạt, giả thuyết được đưa ra là các phần tử trong mô hình thay thế cho trứng cá và số phân tử được thả là 5.000 tương đương 5.000 trứng tại một vị trí. Thời gian âp trứng từ khi đẻ đến khi nở được tính xấp xỉ 30 giờ, cá bột ở giai đoạn noãn hoàng sau khi nở là 13 giờ, cá bột chưa hình thành vây đuôi sau khi hấp thu hết noãn hoàng là 96 giờ [18]. Các thông số sinh học như mức chết của trứng, tác động sinh học nội tại của trứng và phát triển cá bột ở giai đoạn chưa hình thành vây đuôi không ảnh hưởng đến quá trình vận chuyển.

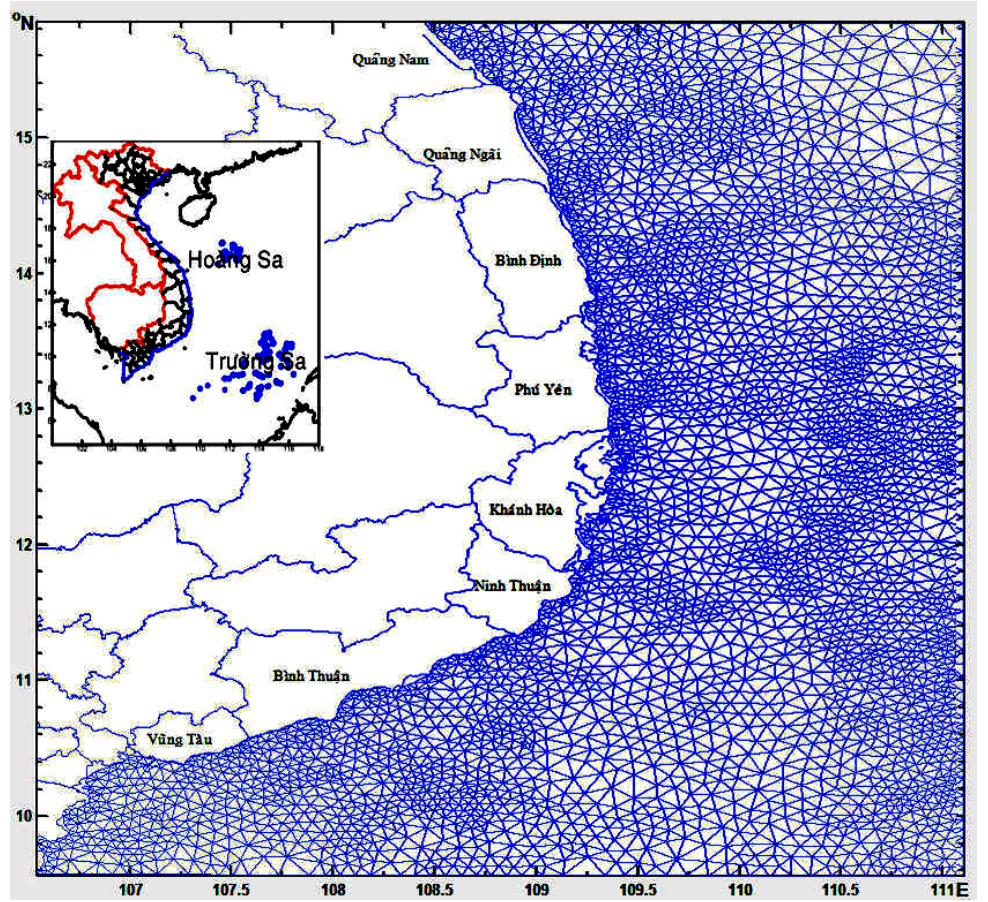

Hình 2. Mạng lưới tam giác thiết lập cho mô hình vận chuyển trứng cá ở vùng nước trồi Nam Trung bộ 


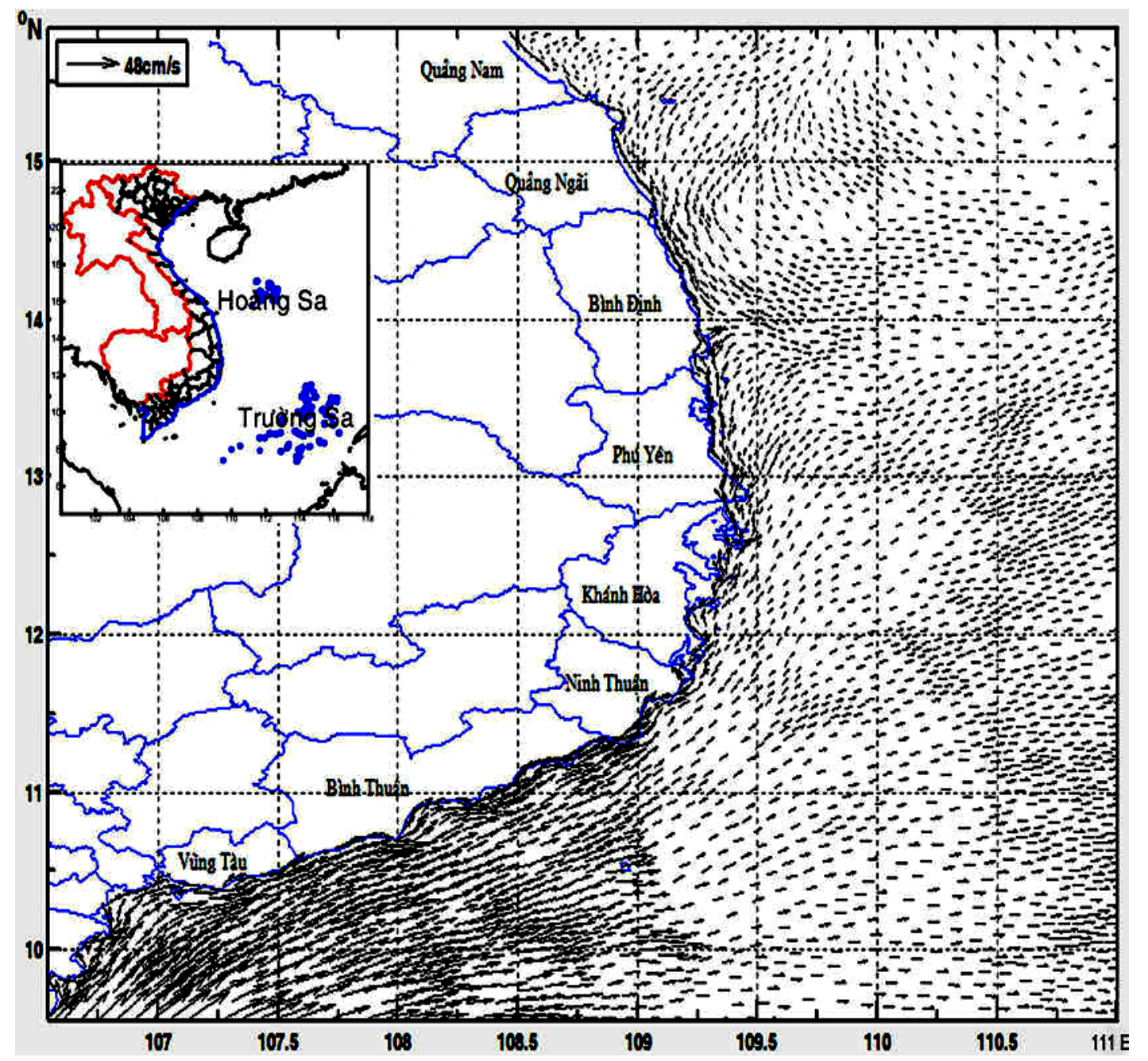

Hình 3. Dòng chảy tầng mặt trong mùa gió Tây Nam sử dụng cho mô hình vận chuyển trứng cá ở vùng nước trồi Nam Trung bộ

\section{KẾT QUẢ NGHIÊN CÚ̉ VÀ THẢO LUẬN}

\section{Phân bố trứng cá và cá bột.}

Vào tháng 7/2003, trứng cá xuất hiện tại các vị trí ven bờ như trạm 41 và 51 , cá bột ngoài khu vực tập trung ở ven bờ giống như trứng cá chúng còn xuất hiện mật độ khá cao ở khu vực ngoài khơi là trạm 13. Các khu vực khác đều có mật độ rất thấp (hình 4). Trong tháng 4/2004, trứng cá tập trung dọc theo các trạm ven bờ như 41, 51 và 62 , nhưng cá bột xuất hiện ở các trạm ngoài khơi là trạm 55 và 66 (hình 4). Vào tháng 7/2004, trứng cá cũng có xu hướng phân bố vùng ven bờ giống như vào tháng 7/2003 ở khu vực cá trạm: 41, 42, 62 và 63. Cá bột phân bố trong khu vực như trứng cá ở tầng mặt, nhưng ở lưới thẳng đứng cho thấy cá bột lại xuất hiện từ $10-30$ con $/ 100 \mathrm{~m}^{3}$ ở các trạm ngoài khơi 55 , 56 và 65 (hình 5 ). Vào tháng $3 / 2005$, trứng cá cũng có xu hướng phân bố dọc theo ven bờ (các trạm $21,31,41,51$ và 62 ), cá bột có mật độ rất thấp, xuất hiện ven bờ và ở các trạm 42 và 52 xa bờ hơn trong lưới thẳng đứng (hình 5 ). 

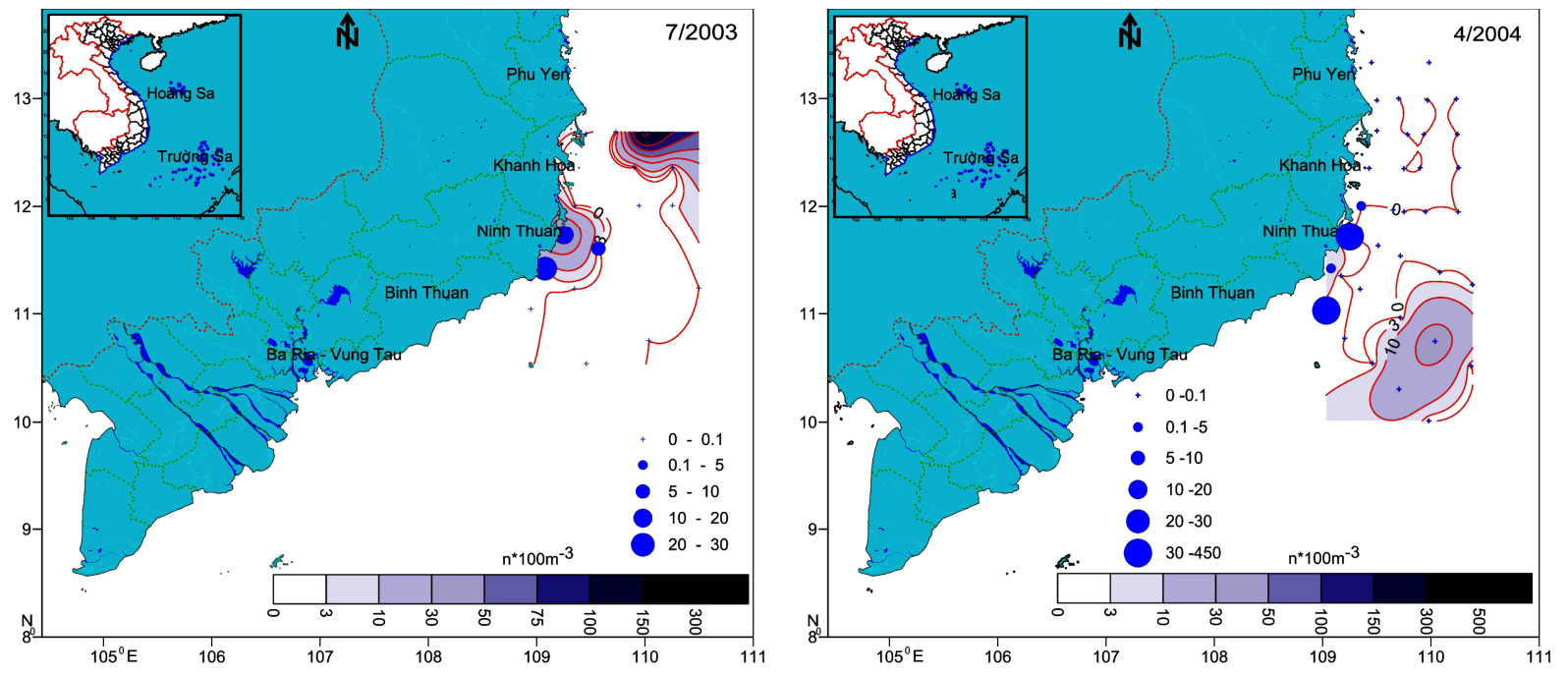

Hình 4. Phân bố trứng cá và cá bột cá cơm sọc xanh vào tháng 7/2003 và 4/2004 (điểm là trứng cá và đường đẳng là cá bột)
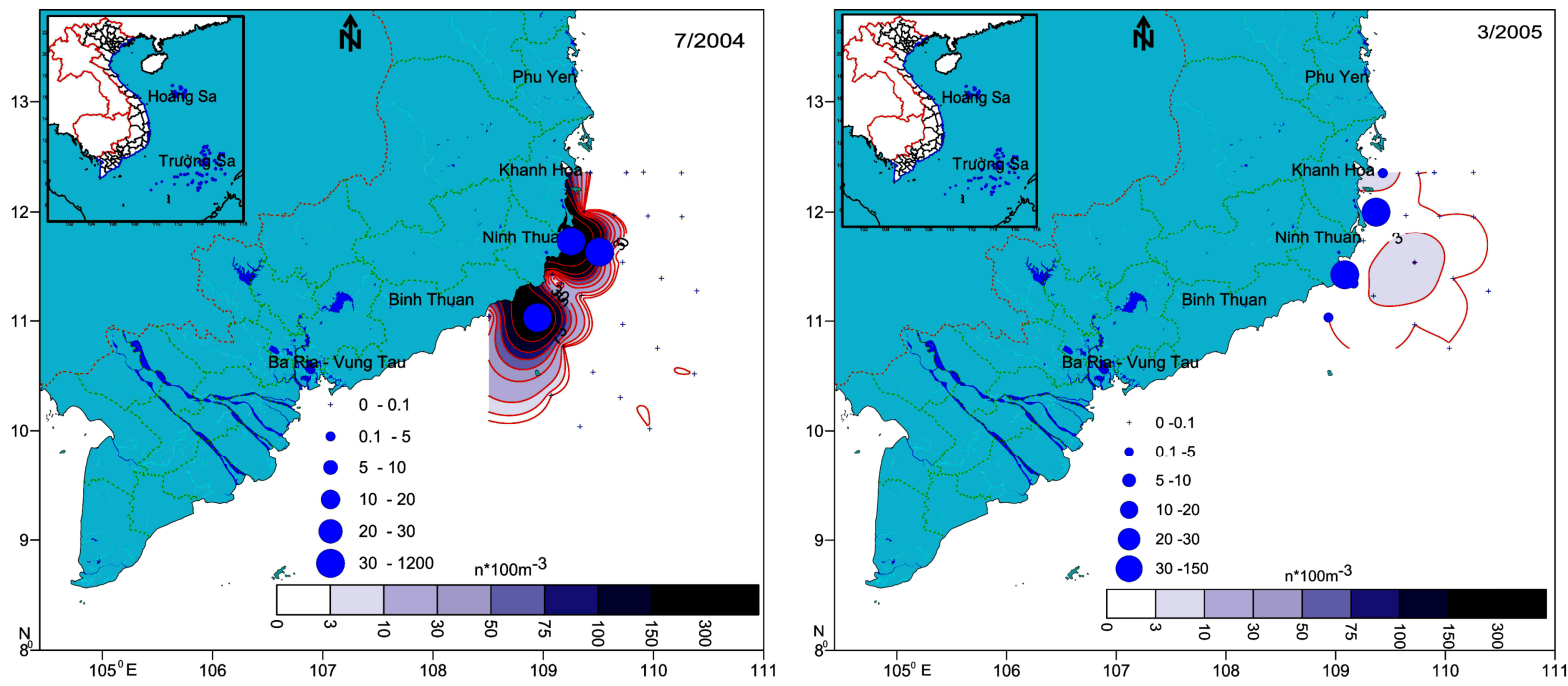

Hình 5. Phân bố trứng cá và cá bột cá cơm sọc xanh vào tháng 7/2004 và 3/2005 (điểm là trứng cá và đường đẳng là cá bột)

\section{Vận chuyển của trứng cá}

Kết quả thực nghiệm mô hình vận chuyển trứng cá và cá bột ở giai đoạn đầu của cá bột sau 144 giờ (6 ngày). Khu vực thả nằm ở khu vực thu được nhiều trứng vào tháng 7 năm 2003 và 2004. Sau 6 giờ các phần tử nằm ở vị trí thả ban đầu, do chưa có lực phân tán của nước và gia tốc dòng chảy. Sau 48 giờ dưới tác động của dòng chảy chúng được đưa lên hướng Bắc ven theo vùng bờ, đến 84 giờ các phần tử phân tán ra xung quanh trong quá trình di chuyển, một số phần tử được đưa vào vùng ven bờ phía Bắc Ninh Thuận, Cam Ranh, vịnh Nha Trang và cửa vịnh Vân Phong. Các phần tử còn lại được đưa ra vùng khơi (hình 6 - 11). 


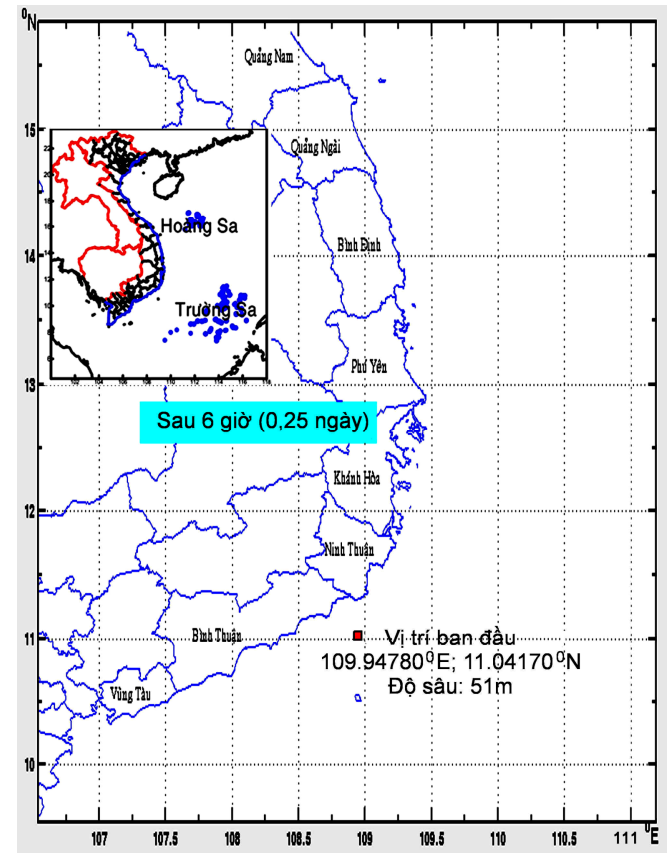

Hình 6. Kết quả mô phỏng vận chuyển trứng cá cá cơm sọc xanh

vào mùa gió Tây Nam ở vùng nước trồi Nam Trung bộ sau 6 giờ

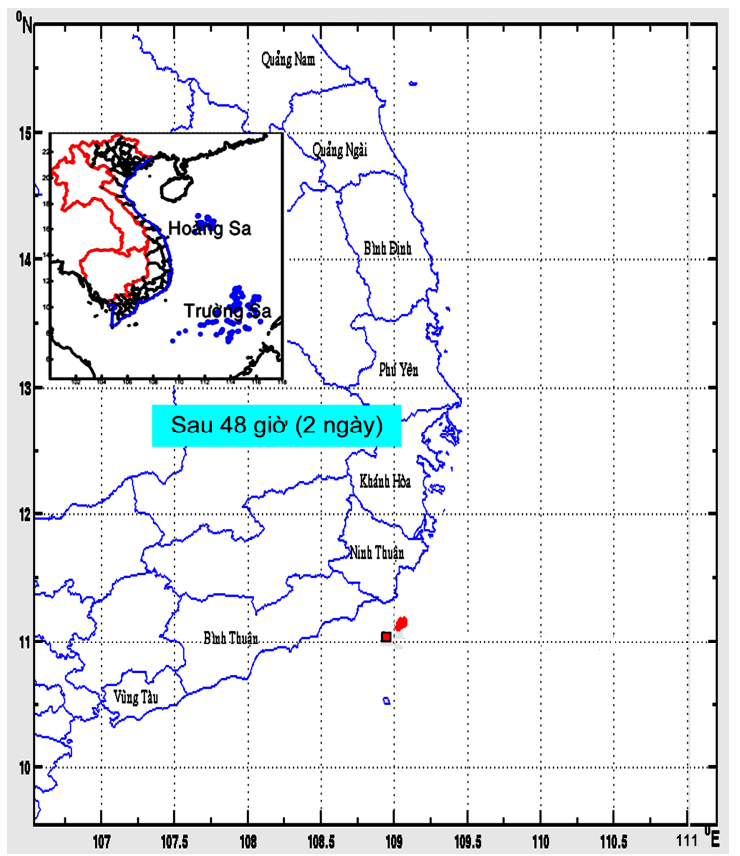

Hình 8. Kết quả mô phỏng vận chuyển trứng cá cá cơm sọc xanh vào mùa gió Tây Nam ở vùng nước trồi Nam Trung bộ sau 48 giờ, màu đỏ là phần tử phát tán

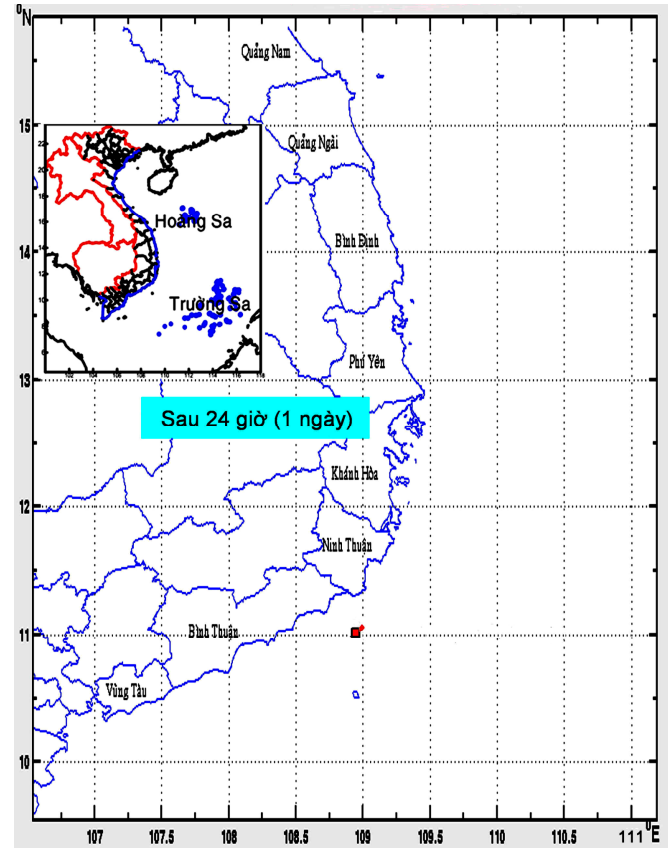

Hình 7. Kết quả mô phỏng vận chuyển trứng cá cá cơm sọc xanh vào mùa gió Tây Nam ở vùng nước trồi Nam Trung bộ sau

24 giờ, phần tử bắt đầu di chuyển

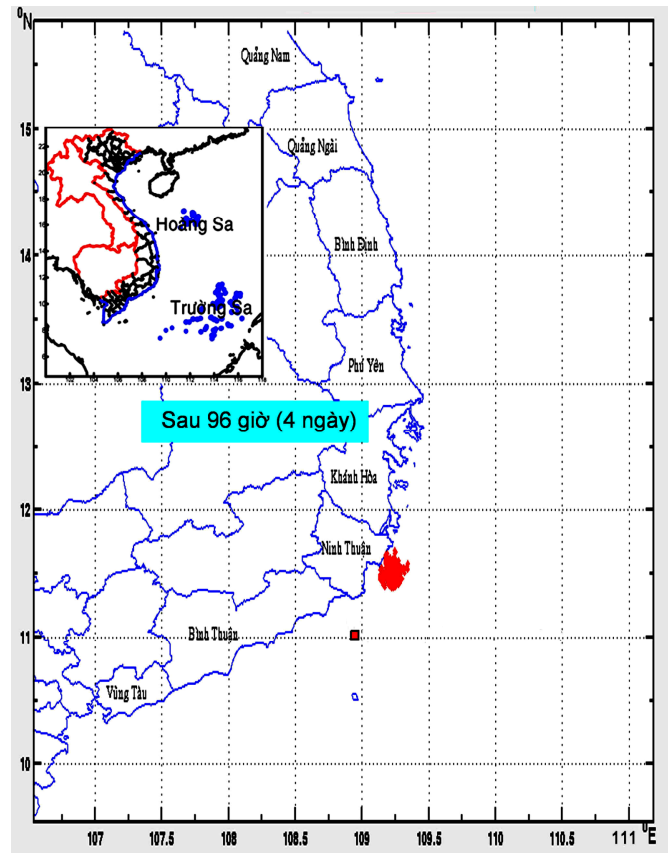

Hình 9. Kết quả mô phỏng vận chuyển trứng cá cá cơm sọc xanh vào mùa gió Tây Nam ở vùng nước trồi Nam Trung bộ sau 96 giờ, màu đỏ là phần tử phát tán 


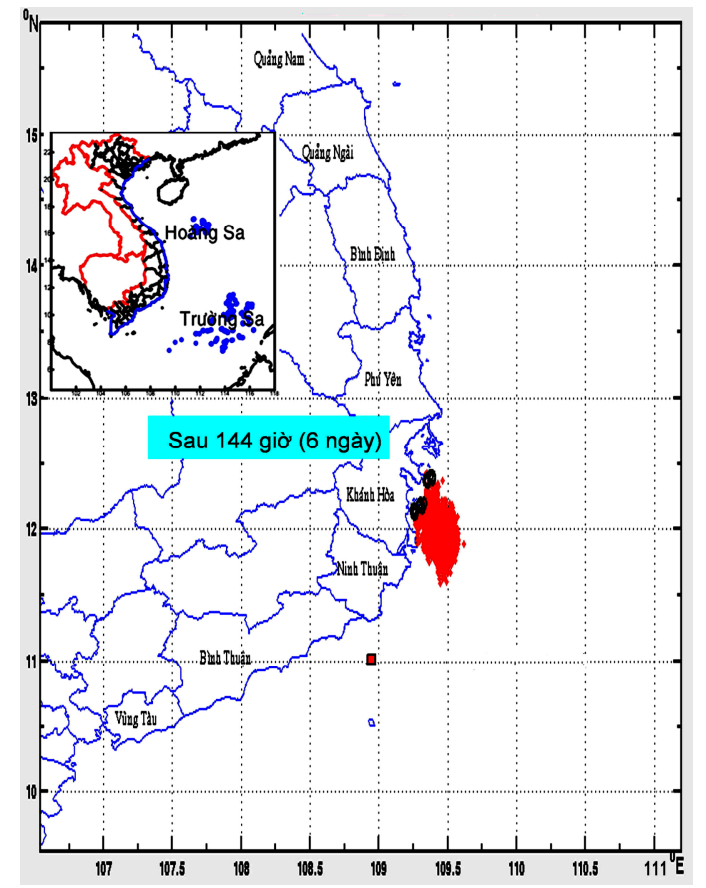

Hình 10. Kết quả mô phỏng vận chuyển trứng cá cá cơm sọc xanh vào mùa gió Tây Nam ở vùng nước trồi Nam Trung bộ sau 144 giờ, màu đỏ là phần tử thả ban đầu và màu đen là phần tử được đưa vào vùng ven bờ

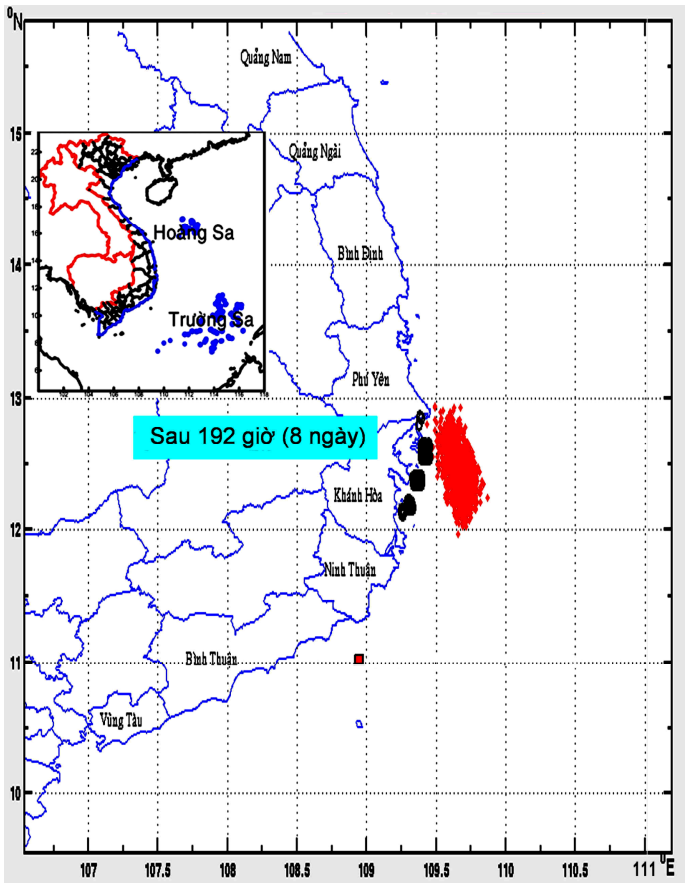

Hình 11. Kết quả mô phỏng vận chuyển trứng cá cá cơm sọc xanh vào mùa gió Tây Nam ở vùng nước trồi Nam Trung bộ sau 240 giờ, màu đỏ là phần tử được thả và màu đen là phần tử được đưa vào vùng ven bờ

\section{Thảo luận}

Dựa vào kết quả thu được các tháng ở thời kỳ chuyển mùa (tháng 3,4 ) và gió mùa Tây Nam chính (tháng 7) cho thấy rằng mật độ trứng cá và cá bột khá cao trong mùa gió Tây Nam chính (tháng 7); thời kỳ có nước trồi hoạt động, ở các tháng này vận tốc và cường độ gió cũng có thể khác nhau từng năm, do đó hoạt động nước trồi cũng khác nhau. Quá trình nước trồi vùng biển này còn chịu tác động của khối nước từ sông Mê Kông [19]. Ngược lại vào các tháng 4/2004 mật độ trứng cá và cá bột có xu hướng thấp hơn tháng 7/2004, vào tháng 3/2005 có mật độ thấp nhấp. Tuy nhiên vào tháng 07/2003 mật độ trứng cá lại tương đối thấp (hình 12), theo kết quả phân tích, thì năm 2003 là năm có hiện tượng El Niño yếu với nhiệt độ nước tầng mặt vùng Biển Đông khá cao đã ảnh hưởng đến cường độ nước trồi $[5,6]$. Loài cá cơm sọc xanh sinh sản quanh năm, có hai đỉnh chính là tháng 3 5 và tháng $9-11$ [8]. Mật độ trứng cá loài cá cơm sọc xanh trong vịnh Nha Trang cũng thấy mùa đẻ từ tháng 3 - 5 và tháng 9 - 11; tương ứng với các tháng các mật độ trứng cá cao [16]. Từ kết quả cho thấy rằng khu vực nước trồi có mật độ trứng cá và cá bột của loài cá cơm sọc xanh khá cao, từ đó có thể nhận định nước trồi với các điều kiện môi trường và sinh học thuận lợi đã kích thích cá đẻ trứng vào thời kỳ nước hoạt động mạnh. Kết quả này là cơ sở để đánh giá vai trò và ý nghĩa nước trồi đối với sự sinh sản của cá, nó cũng phù hợp với nhận định về quá trình nước trồi đã kích thích thêm một đỉnh sinh sản nữa đối với cá [11]. Sự tác động của nước trồi đến mức độ đẻ trứng, bãi đẻ của cá bố mẹ và phân 
bố của trứng cá và cá bột có thể xê dịch về mặt không gian; tuy nhiên xu hướng chung cho thấy bãi đẻ của loài cá cơm sọc xanh tập trung dải ven bờ, trong khi đó cá bột tập trung ở các khu vực rìa của tâm nước trồi. Sự phân bố tập trung của trứng cá hay bãi đẻ của cá bố mẹ ở ven bờ là phù hợp với kết quả phân tích về phân bố trứng cá loài cá cơm sọc xanh từ Khánh Hoà đến Bà Rịa-Vũng Tàu [18].

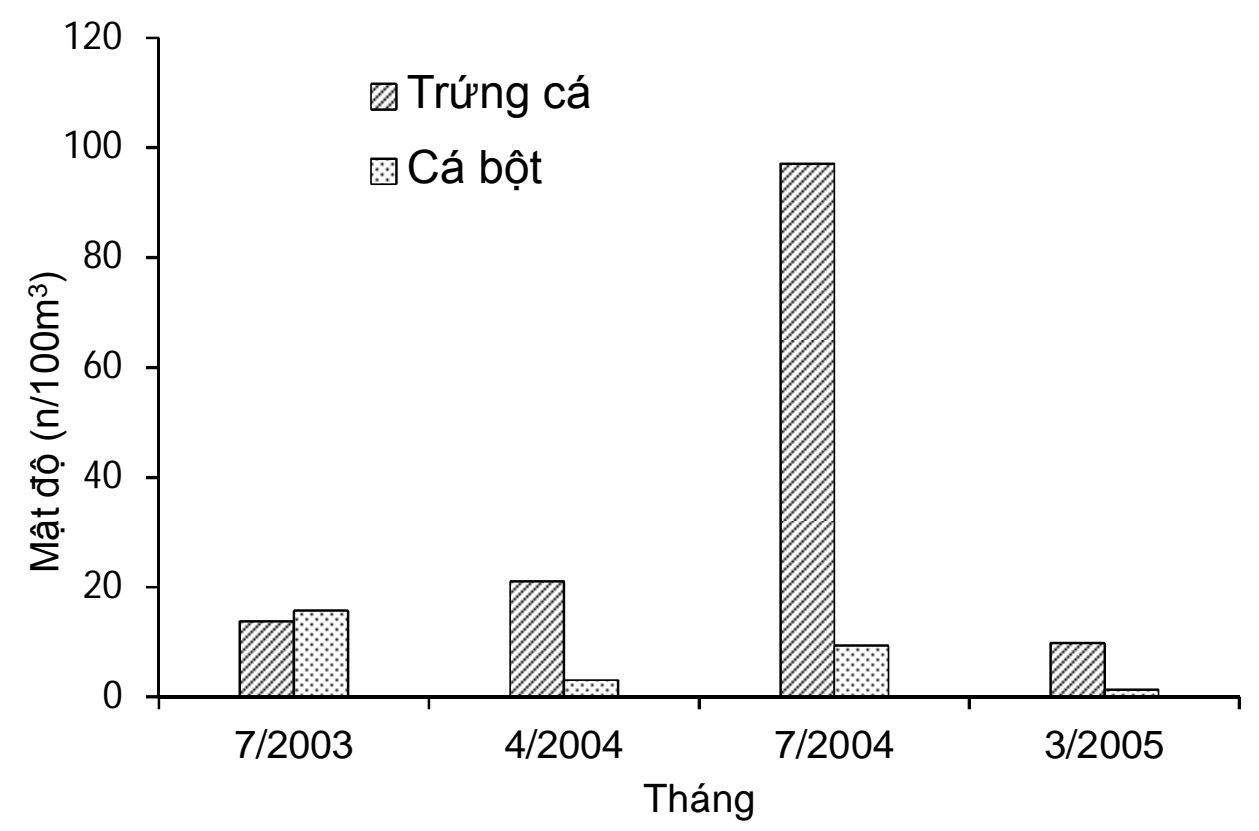

Hình 12. So sánh mật độ trứng cá và cá bột cá cơm sọc xanh ở các chuyến khảo sát

Sự vận chuyển và phân tán có ý nghĩa nhất định trong việc đưa cá bột đến các khu vực ương dưỡng có điều kiện sống thích hợp cho phát triển con non. Kết quả mô hình vận chuyển trứng cá và cá bột cho thấy chúng được dòng nước đưa vào vùng ven bờ, nơi có các rạn, đảo, vũng vịnh, là những nơi ương dưỡng thuận lợi cho cá con. Sự xuất hiện cá bột với mật độ cao ở vùng ngoài khơi vào tháng 7/2003 có khả năng do dòng chảy đưa trứng cá từ bờ ra khơi. Mô hình vận chuyển trứng cá và cá bột cá cơm sọc xanh bước đầu chỉ mô phỏng thời kỳ gió mùa Tây Nam (tháng 7 - 8) vào năm 2003 - 2004, cho kết quả tương đồng với kết quả về hoạt động mùa gió Tây Nam yếu [6].

\section{NHẬN XÉT}

Trứng cá tập trung ở các trạm khu vực ven bờ Ninh Thuận - Khánh Hòa, mật độ trứng cá và cá bột loài cá cơm sọc xanh khá cao vào tháng 7 . Từ đó cho thấy bãi đẻ loài cá này là vùng ven bờ.

Cá bột tập trung phân bố ven bờ như trứng cá, nó còn xuất hiện với mật độ cao ở vùng ngoài khơi. Hiệu ứng của quá trình nước trồi khu vực Nam Trung bộ có thể đã tạo các điều kiện thuận lợi cho sự sinh sản của loài cá cơm sọc xanh trong vùng biển này.

Mô hình mô phỏng sự vận chuyển trứng cá cho thấy chúng được đưa đến vùng ven bờ phía bắc Ninh Thuận, Cam Ranh, vịnh Nha Trang và cửa vịnh Vân Phong. 


\section{TÀI LIỆU THAM KHẢO}

1. Bailey, K. M. and E. D. Houde, 1989. Predation on eggs and larvae of marine fishes and the recruitment problems. Advances in Marine Biology, Vol. 25: 1-83.

2. Bùi Hồng Long và Trần Văn Chung, 2009. Tính toán dòng chảy trong khu vực nước trồi Nam Trung bộ bằng mô hình dòng chảy ba chiều (3-D) phi tuyến. Tạp chí Khoa học và Công nghệ Biển, Tập 9, Số 2 , tr. 1-25.

3. Cowan, J. H. Jr. and R. F. Shaw, 2002. Recruitment. Chapter 4. in "Fishery Science: The Unique Contributions of Early Life Stages" edited by L. A. Fuiman and R. G. Werner, Blackwell Science: 88-111.

4. Delsman, H.C., 1931. Fish eggs and larvae from the Java sea. 17. The genus Stolephorus, Treubia, 13 (3): 217-243.

5. Dippner J. W., Vinh N. K., H. Hein, T. Ohde . N. Loick, 2007. Monsoon-induced upwelling off the Vietnamese coast, Ocean Dynamics 57: 46-62.

6. Dippner, J.W., Nguyen N.L., Doan-Nhu H., Subramaniam A., 2011. A model for the prediction of harmful algae Blooms in the Vietnamese upwelling area. Harmful Algae, Article in Press, Corrected Proof . DOI:10.1016/j.hal.2011.04.012.

7. Lã Văn Bài và Võ Văn Lành, 1997. Đặc điểm phân bố và cấu trúc nhiệt muối vùng nước trồi mạnh. Tuyển tập Nghiên cứu vùng nước trồi Nam Trung bộ, tr. 39-46.

8. Lê Trọng Phấn và Nguyễn Văn Lục, 1991. Đặc điểm sinh học giống cá cơm Stolephorus ở vùng biển ven bờ Việt Nam. Tuyển tập Nghiên cứu Biển. Nxb. Khoa học và Kỹ thuật. Tập III, tr. 51-58.

9. Leis, J. M. \& B. M. Carson-Ewart, 2000. The Larvae of Indo - Facific Coastal Fishes. Fauna Malesiana Handbook 2, Netherlands: 82-87.

10. Nguyễn Hũu Phụng, 1978. Trứng cá cơm (Anchoviella) ở ven biển Quảng Ninh - Hải Phòng. Tuyển tập Nghiên cứu Biển. Nxb. Khoa học và Kỹ thuật. Tập I, Phần I, tr. 175-189.

11. Nguyễn Hữu Phụng,1997. Trứng cá và cá bột vùng nước trồi mạnh Nam Trung bộ. Tuyển tập Các công trình nghiên cứu vùng nước trồi Nam Trung bộ. Nxb. Khoa học và Kỹ thuật, tr. 156-165.

12. Nguyễn Văn Lục, 1997. Một vài đặc trưng sinh học cá biển vùng nước trồi mạnh Nam Trung bộ. Tuyển tập Các công trình nghiên cứu vùng nước trồi Nam Trung bộ. Nxb. Khoa học và Kỹ thuật, tr. 192-203.

13. Ozawa, T. and H. Tsukahara, 1986. On the occurrence of the Engraulid fish, Stolephorus buccaneeri Strasburg, in the oceanic region of the Equatorial western Pacific. In "Studies on the oceanic ichthyoplankton in the western north pacific" edited by T. Ozawa. Kyushu University press: 8-28.

14. Pauly, D. and V. Christensen, 1995. Primary production required to sustain global fisheries. Nature (374): 255-257.

15. Smith, P. E., 1981. Fisheries on coastal pelagic schooling fish. In "Marine fish larvae: Marine fish larvae: morphology, ecology, and relation to fisheries" Edited by R. Lasker, Washing sea grant program:1-31. 
16. Võ Văn Quang và Trần Thị Lê Vân, 2005. Biến động mật độ trứng cá của loài cá cơm sọc xanh Stolephorus zollingeri (Bleeker, 1849) ở vùng biển vịnh Nha TrangKhánh Hòa. Tạp chí Khoa học và Công nghệ Biển. Phụ trương số 4(5), tr. 129-138.

17. Võ Văn Quang và Trần Thị Lê Vân, 2008. Phân bố trứng cá loài cá cơm sọc xanh (Encrasicholina punctifer) ở vùng biển Khánh Hòa đến Bà Rịa-Vũng Tàu. Hội nghị khoa học "Biển Đông - 2007", Viện Hải dương học Nha Trang. Nxb. Khoa học và Kỹ thuật, tr. 425-432.

18. Võ Văn Quang và Trần Thị Lê Vân, 2010. Đặc trưng hình thái và ảnh hưởng nhiệt độ lên phát triển phôi của trứng loài cá cơm sọc xanh (Ecrasicholina punctifer). Tuyển tập Nghiên cứu Biển. Nxb. Khoa học và Kỹ thuật. Tập XVII , tr. 99-107.

19. Voss, M.,D. Bombar, N. Loick, and J. W. Dippner, 2006. Riverine influence on nitrogen fixation in the upwelling region off Vietnam, South China Sea. Geophysical Research Letters, Vol. 33, L07604: 1-4.

20. Wyrtki, K., 1961. Physical Oceanography of the Southeast Asian Waters. NAGA Report, Vol. 2, La Jolla, California, 195pp.

21. Young, S. S., Chiu T.S. and Shen S. C.,1995. Taxomony, description and distribution of larval anchovy (Engraulidae) occurred in the waters around Taiwan.. Acta Zoologica Taiwanica 6 (1): 33-60.

\title{
MODELLING DISTRIBUTION AND TRANSPORT PROCESSES OF RED ANCHOVY FISH EGGS AND LARVAE (Encrasicholina punctifer) IN THE UPWELLING WATERS OF SOUTH CENTRAL VIET NAM
}

\author{
VO VAN QUANG, TRAN VAN CHUNG
}

\begin{abstract}
Summary: Distribution of fish eggs and larvae of red anchovy is variable in July 2003, April 2004, July 2004 and March 2005 in the upwelling waters of Vietnam. The upwelling process marked to the responses of adult who released the eggs in the strong upwelling period (June - August). The density of fish eggs of red anchovy are most abundant in the southwestern monsoon (July 2003 \& 2004). Although the difference between the climatic means during all seasons, a clear tendency exists with high density of fish eggs in spawning ground of inshore waters (stations: 41, 42, 51, 52, 62, and 63). The distribution of larvae is different in comparison with eggs that demonstrate the influence of circulation of the mass waters through diffusion, transport and retention of larvae into the coastal zone such as bays and islands where are successfully for recruitment process of red anchovy population.
\end{abstract}

Ngày nhận bài: 30 - 8 - 2011

Người nhận xét: PGS.TS. Nguyễn Hữu Phụng 